\title{
Comparison and analysis of conversion methods for self- balancing test of pile bearing capacity
}

\author{
Yonggang Qiu ${ }^{1, *}$,Chuansheng $H u a n g^{1}$, Renhao $H o n g^{1}$,Chunhan $C h e n^{1}$, Jinxiang $Y i^{1}$, and Weixiong $L i^{1}$ \\ 1 School of Civil and Architectural Engineering, East China University of Technology, Nanchang, Jiangxi, China
}

\begin{abstract}
The principle and method of self-balancing test are introduced briefly. In this article, through comparison of common Q-S curve of equivalent transformation to transform from the balance of the measured load-displacement curve for the tradition- al method of load - displacement curve, puts forward the advantages and disadvantages of each, through the three bored piles in static load test of pile reaction from balance to detect vertical compressive ultimate bearing capacity of single pile is in line with the requirements and compare the load-displacement curve after conversion. Some problems of the self-balancing method in engineering are pointed out, which is of certain reference value to the popularization and application of the self-balancing test of pile bearing capacity.
\end{abstract}

\section{Introduction}

Common single pile bearing capacity testing methods include pile foundation static load test, pile loading test method and self-balancing test method. However, compared with the three methods, self-balancing test method has lower cost, is not limited by the site, and is efficient. There are many methods to transform the traditional static load results. As is known to all, the whole pile t- op load settlement curve is the most reliable data to describe the performance of a single pile. Common conversion methods include equal displacement method, equal load method, simplification method and so on. This paper summarizes and analyses the methods of converting the results of self-balancing test of pile bearing capacity into the results of traditional static load, and makes a comparative analysis of various methods with examples, and points out some problems existing in the engineering of self-balancing method.

\section{Self-balancing static load test}

\subsection{Testing principle}

The self-balancing test method is a new static load test method. The ultimate bearing capacity of the pile is tested by burying load cell in the pile body, loading upward and downward along the vertical direction, and using the pile side resistance as the reaction force of the pile end resistance.Used to judge the bearing capacity of pile foundation, pile foundation settlement, pile elastic compression and rock and soil plastic deformation[2].The curve of lateral friction resistance of the pile can be measured at the same time if the reinforcement gauge and other strain measuring instruments are arranged at different elevations of the pile. The ultimate bearing capacity of the whole pile can be calculated by obtaining the ultimate bearing capacity of the upper and lower pile bodies[3-4]. The self-balancing compressive static load test device is shown in Figure 1.

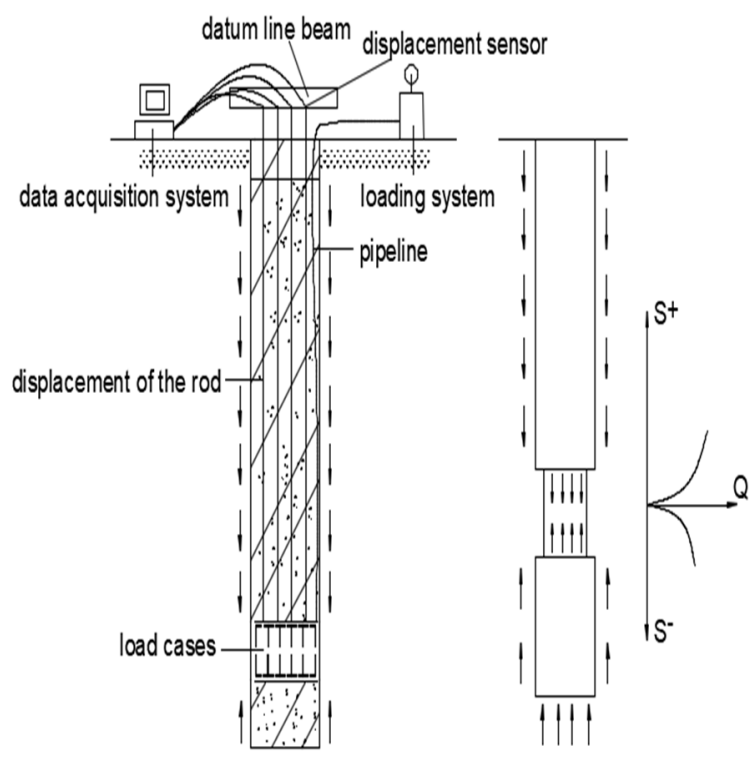

Figure1 self-balancing static load test diagram of foundation pile

\subsection{Determination of vertical compressive ultimate bearing capacity of single pile}

According to Technical Specification for Static Load Test of Pile Self Reaction Force Balance (DB36/J002-2006) [1], the calculation formula of vertical compressive ultimate

\footnotetext{
*Corresponding author: 1536421532@qq.com
} 
bearing capacity of a single column tested by the selfbalancing method is as follows:

$$
\begin{gathered}
Q_{u-u p}=Q_{u-\text { down }} \\
\mathrm{W}=\pi \times(D / 2)^{2} \times L_{u p} \times \rho \\
Q_{u}=\frac{Q_{u-u p}-W}{\gamma}+Q_{u-\text { down }}
\end{gathered}
$$

Where: $\mathrm{Q}_{\mathrm{u}^{--}}$the vertical compressive ultimate bearing capacity of a single pile;

$\mathrm{Q}_{\mathrm{u}-\mathrm{up}}-\mathrm{-}$ the ultimate bearing capacity of the upper pile of the load cell;

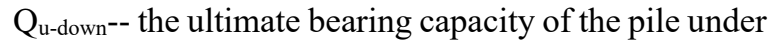
the load cell;

W-- the dead weight of the upper pile of the load cell;

$y$-- Correction coefficient of pile lateral friction of the upper pile of load cell.

For clay and silt, $y=0.8$; For sandy soil, $y=0.7$.

\section{Self-balancing conversion method}

\subsection{Principle of equal displacement method}

Equal displacement method is to draw $Q_{1}-S_{1}$ and $Q_{2}-$ $\mathrm{S}_{2}$ curves through the load value of each load cell and the displacement of pile. Based on the method of superimposed load by displacement, the following formula can be obtained according to the above principles:

$$
\begin{gathered}
Q^{i}=\frac{Q_{1}^{i}}{\lambda_{1}}+Q_{2}^{j} \\
S^{i}=S_{1}^{i}=S_{2}^{j}
\end{gathered}
$$

Where, $Q_{1}^{i}, Q_{2}^{j}$ are the upward and downward loads of the load cell at points $i$ and $j$ respectively; $S_{1}^{i}, S_{2}^{j}$ are the upward and downward displacement of the load cell at points $\quad \mathrm{i}$ and $\mathrm{j}$ respectively. According to equations (1) and (2), a series of points in the traditional static load test can be obtained, thus obtaining the Q-S curve.

\subsection{Principle of equal load method}

According to the principle of equal load way. The following formula can be obtained:

$$
\begin{gathered}
Q^{i}=Q_{1}^{i} / \lambda_{1}+Q_{2}^{i} \\
S^{i}=\lambda_{2} \max \left(S_{1}^{i}, \quad S_{2}^{i}\right)
\end{gathered}
$$

Where, $\mathrm{Q}_{1}^{\mathrm{i}} \mathrm{Q}_{2}^{\mathrm{i}}$ are respectively the upward and downward loads of the load cell at point $I ; S_{1}^{i}, S_{2}^{i}$ are respectively the upward and downward displacement of the load cell at point $\mathrm{I} ; \lambda_{2}$ is the displacement correction coefficient, $\left(S_{1}^{i}+S_{2}^{i}\right) / 2 \max \left(S_{1}^{i}, S_{2}^{i}\right)<\lambda_{2}<1$, which is desirable $\lambda_{2}=1$ in practical engineering.

\subsection{Principle of simplification method}

The simplified method needs to adopt the theoretical analysis calculation method. For general engineering, we can use the simplified conversion method in the theoretical analysis calculation method. According to the principle of synchronous upward and downward displacement, the simplified conversion method carries out super position of load through displacement, and the following conversion formula can be obtained:

$$
\begin{gathered}
\Delta S_{1}=\frac{Q_{u-\text { down }} L}{E_{p} A_{p}} \Delta S_{2}=\frac{\left(Q_{\mathrm{u}-u p}-W\right) L / \gamma}{2 E_{p} A_{p}} \\
\Delta S=\Delta S_{1}+\Delta S_{2}, S=S_{u-\text { down }}+\Delta S \\
s=S_{u-\text { down }}+\frac{\left[\left(Q_{u-u p}-W\right) / \gamma+2 Q_{u-\text { down }}\right] L}{2 E_{p} A_{p}} \\
Q_{u}=\frac{Q_{u-u p}-W}{\gamma}+Q_{u-\text { down }}
\end{gathered}
$$

Where, $\mathrm{Q}_{\mathrm{u} \text {-up }}$ and $\mathrm{Q}_{\mathrm{u} \text {-down }}$ are the ultimate bearing capacity of the upper and lower piles of the load cell; $\triangle$ $\mathrm{S}_{1}$ is the elastic compression deformation of the upper section of the pile under the $Q_{u-d o w n}$ action; $\triangle S_{2}$ is the elastic compression deformation of the upper section of the pile under compression under the action of lateral friction; $\mathrm{W}$ is the dead weight of the upper pile of the load cell; $\mathrm{S}_{\mathrm{u} \text {-down }}$ is the displacement of the bottom position of the load cell; $L$ for the pile length; $E_{p}$ is elastic modulus of pile; $A_{p}$ is the cross-sectional area of the pile; $y$ correction coefficient of lateral friction of upper pile of load cell[5]. The pile top load and pile top displacement corresponding to each stage are calculated, and a series of points are obtained. The equivalent pile top load-displacement curve can be obtained by connecting the points.

\subsection{Comparison of characteristics of the three methods}

In the equal displacement method, when the difference between $S_{1}^{i}$ and $S_{2}^{i}$ is small, the fitting Q-S curve is close to the Q-S curve obtained from the conventional static load test. However, in practical work, the displacements of upper and lower sections differ greatly, so it is impossible to find out the corresponding load when the upper and lower displacements are equal, so a complete Q-S curve can not be obtained. Under the condition of equal displacement $\left(S^{i}=S_{1}^{i}\right)$ with the method of equal load, the value obtained $Q^{i}$ by Equation (3) is less than that obtained $\mathrm{Q}^{\mathrm{i}}$ by Equation (1), so the Q-S curve obtained by this method is lower than that obtained by common methods[6]. The method makes it easier to determine the ultimate bearing capacity in practical engineering, and the obtained value of the ultimate bearing capacity is more safe. The simplified method is applicable in engineering, considering the conversion coefficient and pile compression deformation[7].

\section{Engineering Examples}

\subsection{Engineering test overview}

The foundation of a project is designed as reinforced concrete mechanical bored cast-in-place pile, including test pile, $1 \# 2 \# 3 \# 4 \#$ building and basement pile foundation. 
The pile end bearing layer is medium-weathered mudstone siltstone, and the pile diameter is $900 \mathrm{~mm}$ and $1000 \mathrm{~mm}$. Static load design bearing capacity characteristic value is $4500 \mathrm{kN}, 5500 \mathrm{kN}, 6500 \mathrm{kN}$, uplift design bearing capacity characteristic value $1600 \mathrm{kN}, 2100 \mathrm{kN}$, design pile length is not less than 16.5 meters.

The original landform of the project is the I terrace in the alluvial plain of Gan fu, with an elevation of about 16 $\sim 20 \mathrm{~m}$. The geotechnical engineering parameters of the site are shown in Table 1. This time, $16 \#$ pile, 52\# pile of $1 \#$ building and $75 \#$ pile of $2 \#$ building were selected to carry out the pile body reflexively-balanced static load test (slow maintenance load method). The design parameters of self-balanced static load pile and load cell parameters are shown in Table 2.

Table1. The geotechnical engineering parameters of the field.

\begin{tabular}{|c|c|c|c|c|c|c|}
\hline $\begin{array}{c}\text { Name of rock and } \\
\text { soil layer }\end{array}$ & $\begin{array}{c}\text { Average } \\
\text { thickness (m) }\end{array}$ & $\begin{array}{c}\text { Characteristic value } \\
\text { of bearing capacity } \\
\text { Fak }(\mathrm{kPa})\end{array}$ & $\begin{array}{l}\text { Cohesion } \\
(\mathrm{kPa})\end{array}$ & $\begin{array}{l}\text { Internal } \\
\text { friction } \\
\text { Angle }\left(^{\circ}\right)\end{array}$ & 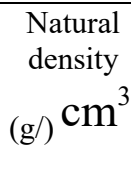 & $\begin{array}{l}\text { Recommended } \\
\text { value of } \\
\text { compression } \\
\text { modulus ES of } \\
\text { soil (MPa) }\end{array}$ \\
\hline Grain filling & 4.13 & 60 & 8.0 & 5.0 & 1.75 & 3.5 \\
\hline silt & 2.28 & 50 & 5.8 & 3.1 & 1.60 & 3.15 \\
\hline Silty clay & 3.36 & 100 & 25.7 & 13.1 & 1.86 & 5.95 \\
\hline Fine sand & 3.17 & 100 & - & 30.0 & 1.95 & 15 \\
\hline Coarse sand & 3.66 & 200 & - & 35.0 & 2.00 & 20 \\
\hline $\begin{array}{l}\text { Highly weathered } \\
\text { argillaceous } \\
\text { siltstone }\end{array}$ & 1.22 & 300 & - & - & - & 25 \\
\hline $\begin{array}{l}\text { Moderately } \\
\text { weathered } \\
\text { argillaceous } \\
\text { siltstone }\end{array}$ & 3.13 & 2000 & - & - & - & - \\
\hline $\begin{array}{l}\text { Calcareous } \\
\text { mudstone }\end{array}$ & 1.98 & 900 & - & - & - & - \\
\hline
\end{tabular}

Table2. The design parameters of self-balanced static load pile and load cell parameters.

\begin{tabular}{|c|c|c|c|c|c|c|}
\hline Pile no. & $\begin{array}{c}\text { Pile } \\
\text { Diameter } \\
(\mathrm{mm})\end{array}$ & $\begin{array}{c}\text { Pile length } \\
(\mathrm{m})\end{array}$ & $\begin{array}{c}\text { Concrete } \\
\text { strength grade }\end{array}$ & $\begin{array}{c}\text { Design } \\
\text { characteristic } \\
\text { value of bearing } \\
\text { capacity of single } \\
\text { pile }(\mathrm{kN})\end{array}$ & $\begin{array}{c}\text { Expanded } \\
\text { low diameter } \\
(\mathrm{mm})\end{array}$ & Load cell diameter (mm) \\
\hline $16 \#$ & 1000 & 16.85 & $\mathrm{C} 35$ & 5500 & $/$ & 800 \\
\hline $52 \#$ & 1000 & 16.54 & $\mathrm{C} 35$ & 5500 & $/$ & 700 \\
\hline $75 \#$ & 900 & 16.55 & $\mathrm{C} 35$ & 4500 & $/$ & 800 \\
\hline
\end{tabular}

\subsection{Result analysis}

The whole test process is normal, the pressure is stable and the curve changes slowly. In this project, $16 \#$ pile, 52\# pile and $75 \#$ pile are all loaded to the maximum test load, and each stage is loaded statically without abnormal phenomenon. Under the maximum load, none of them reaches the termination condition of the specification. Taking $16 \#$ pile, $52 \#$ pile and $75 \#$ pile as examples, the Q$\mathrm{S}$ curves of each pile are shown in figure 2.

As can be seen from figure 2, the upward rebound rate of No.16 pile is $26.9 \%$ and the downward rebound rate is $17.7 \%$. The upward and downward rebound rates of No. 52 pile are $24.5 \%$ and $21.5 \%$ respectively. The upward rebound rate of No.75 pile is $22.2 \%$, and the downward rebound rate is $31.5 \%$.
In this project, the upper part of each test pile load cell is distributed with soil layers, such as moderately weathered argillous siltstone, strongly weathered argillous siltstone, coarse sand, fine sand, silty clay, etc. Considering the burial depth of each soil layer and the pile forming effect of the test pile, the correction coefficient $\gamma=1.0$ is more suitable.No. 16 pile diameter $D=1000 \mathrm{~mm}$, pile length $16.85 \mathrm{~m}$, load to $5700 \mathrm{kN}$, settlement at all levels is relatively uniform, corresponding downward settlement is $12.68 \mathrm{~mm}<40 \mathrm{~mm}$, the measured vertical compressive ultimate bearing capacity of single pile is $11076 \mathrm{kN}>$ $11000 \mathrm{kN}$. No.52 pile diameter $\mathrm{D}=1000 \mathrm{~mm}$, pile length $16.54 \mathrm{~m}$, pile loading to $5700 \mathrm{kN}$, settlement at all levels is more uniform, corresponding downward settlement is $13.06 \mathrm{~mm}<40 \mathrm{~mm}$, the measured vertical compressive ultimate bearing capacity of single pile is $11082 \mathrm{kN}>$ $11000 \mathrm{kN}$.No. 75 pile diameter $\mathrm{D}=900 \mathrm{~mm}$, pile length 
$16.55 \mathrm{~m}$, pile loading up to $4650 \mathrm{kN}$, settlement at all levels is more uniform, corresponding downward settlement is $15.62 \mathrm{~mm}<40 \mathrm{~mm}$, the measured vertical ultimate compressive bearing capacity of single pile is $9042 \mathrm{kN}>$ $9000 \mathrm{kN}$.The measured ultimate bearing capacity of the three piles in vertical compression meets the design requirements.

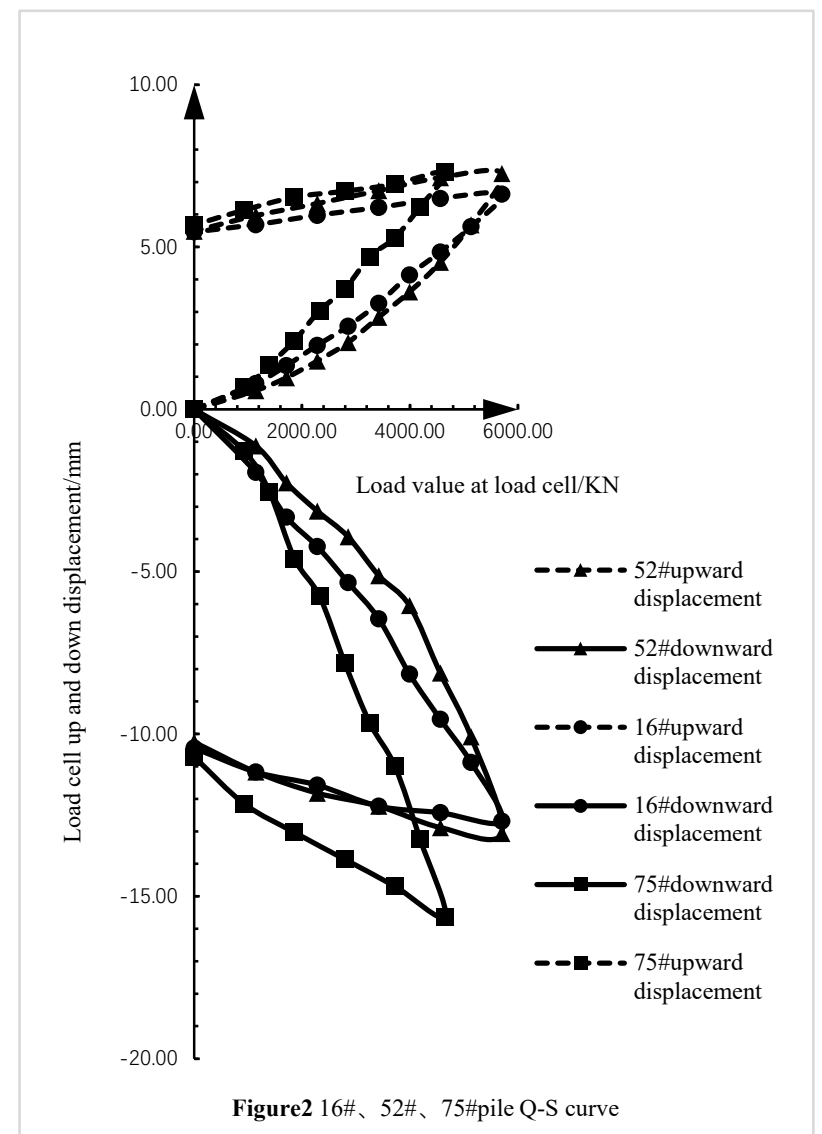

According to the load method, displacement method and simplified method, such as in the actual project $y=1.0$, pulling coefficient $\lambda_{1}=1$, displacement correction coefficient $\lambda_{2}=1$, which is difficult to choose, such as displacement method due to the same displacement by subsection[8], an equation of the generation of value obtained 16 \#, 52 \#, 75 \# pile under the loading qua- ntity per level corresponding to the settlement of pile top is shown in figure 3 , figure 4 , shown in figure 5 .

From figure 3, figure 4, figure 5 shows 16 \#, 52 \#, 75 \# pile equivalent pile top load displacement curve without a significant downward transition period, shows that bearing capacity limit state has not been achieved, the when $S_{1}$ and $S_{2}$ the difference is bigger, such as displacement meth- od to get the $\mathrm{Q}-\mathrm{S}$ curve is not complete, cannot distinguish ultimate bearing capacity, and the lo- ad method and simplified method without the problem, and be safe. The ultimate bearing capacity of $16 \#$, $52 \#$ and $75 \#$ single pile is obtained by using the method of equal load. The displacement of $19.31 \mathrm{~mm}, 20.33 \mathrm{~mm}$ and $22.92 \mathrm{~mm}$ corresponds to the load of $11400 \mathrm{kN}, 11400 \mathrm{kN}$ and $9300 \mathrm{kN}$.Using the simplified method, the ultimate bearing capacity of $16 \#, 52 \#$ and $75 \#$ single pile can be calculated as the load corresponding to the displacement of $18.40 \mathrm{~mm}, 18.67 \mathrm{~mm}$ and $21.28 \mathrm{~mm}$, namely, $11082 \mathrm{kN}$,
$11088 \mathrm{kN}$ and $9047 \mathrm{kN}$. Both methods meet the design requirements. By comparison, it can be seen that the simplified method is safer than the equal-load method, and the equal-load method is safer than the equal-displacement method.

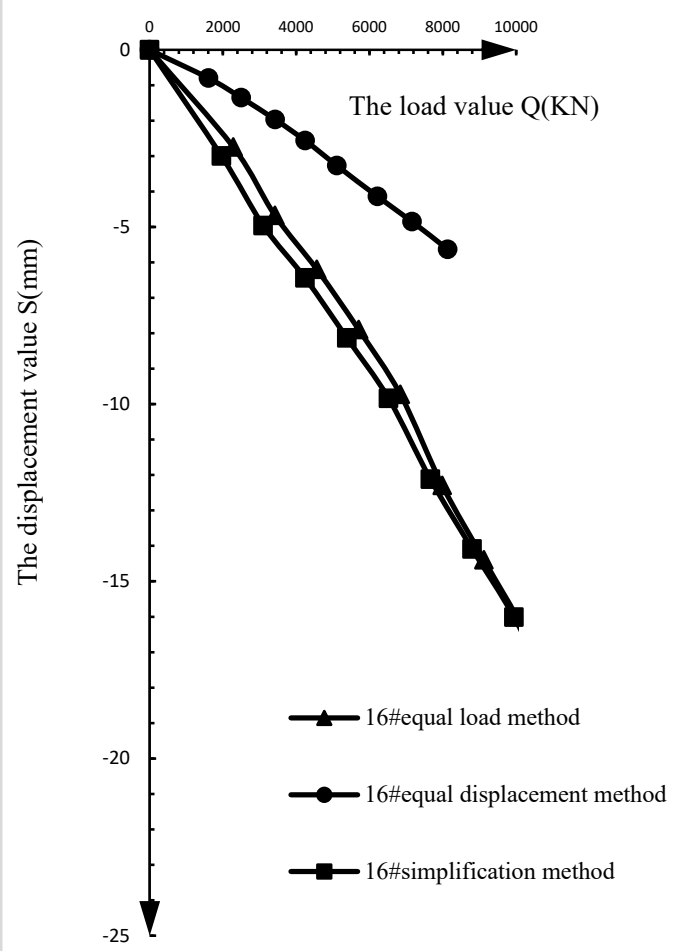

Figure3 Comparison of three conversion methods for $16 \#$ pile

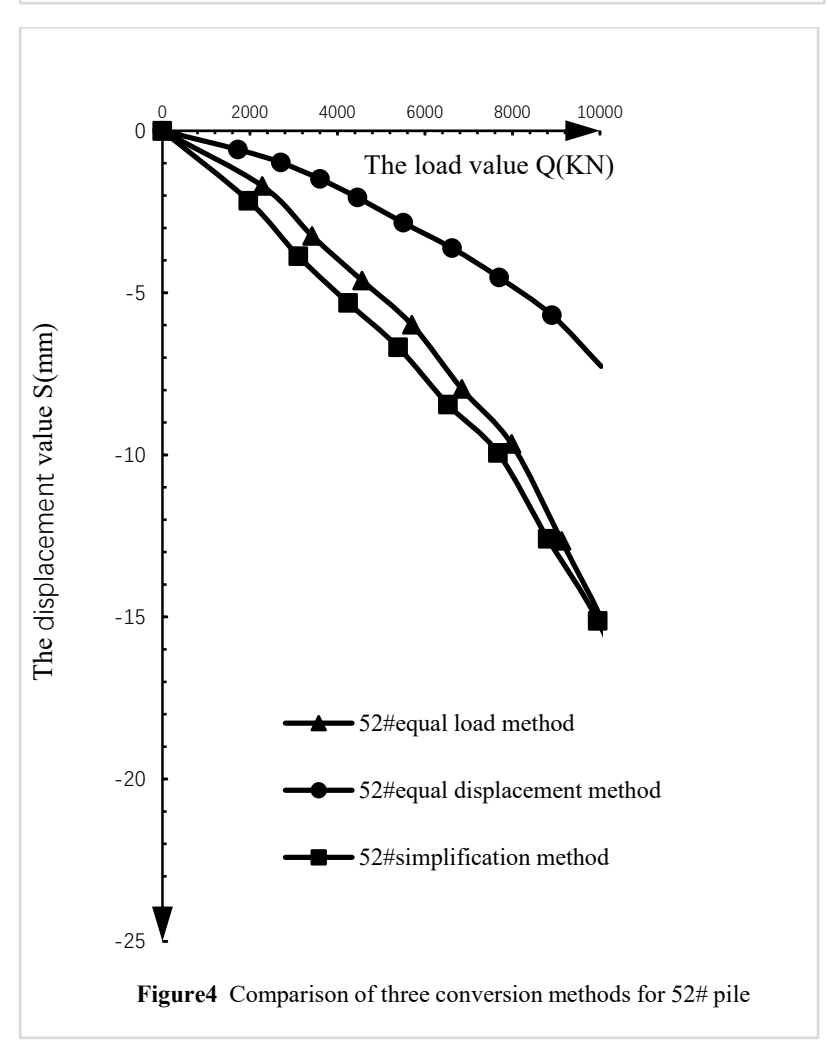




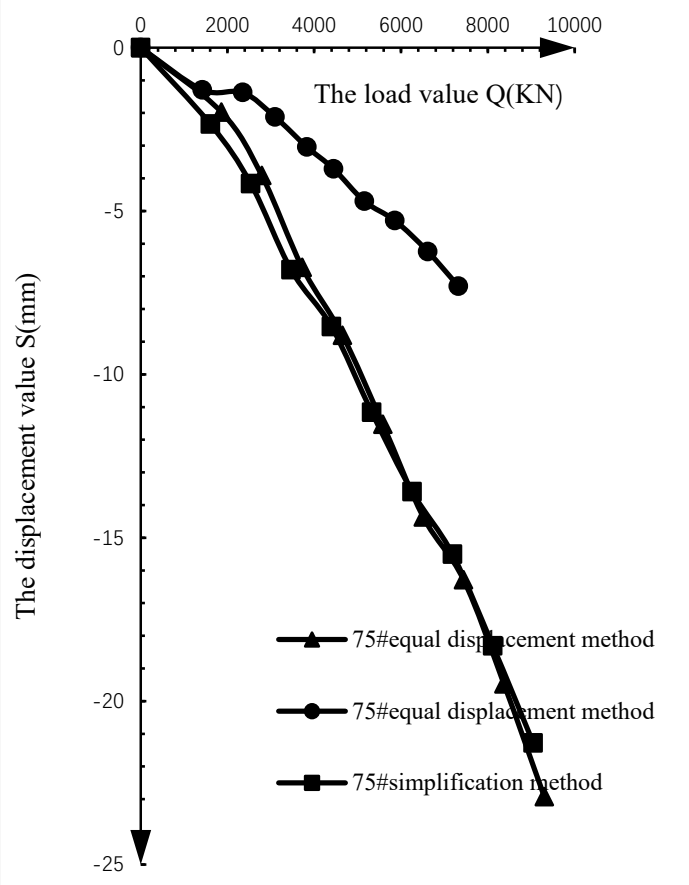

Figure5 Comparison of three conversion methods for $75 \#$ pile

\section{Conclusion}

This paper lists three common methods to comp- are how the $Q_{1}-S_{1}$ and $Q_{2}-S_{2}$ curves measured by the self-balancing method are transformed into the traditional Q-S curve of pile head. The meth- od of reasonable determination of Q$\mathrm{S}$ curve is put forward to meet the requirements of current engineering testing. According to the research status of self-balancing method, the comparison shows that the simplified method is safer than the equal-load method, and the equal-load meth- od is safer than the equaldisplacement method.

\section{References}

1. DB36/J002-2006, Technical Specification for Static Load Test of Reactive Force Balance of Pile [S].

2. Bo Lu, Shaolei Huo, Yunfeng Ge.Experimental analysis of bearing capacity of pile foundation based on self-balancing method [J]. Railway Construction,2009(12):83-86.

3. Shaolei Huo, Jieqing Zhu, Bo Lu. Application of Selfbalancing Pile Measurement Method in Wuhan Building Pile Foundation Engineering [J]. Subgrade Engineering,2009(06):111-113.

4. Dalin Zhang, Weiming Gong, Qinjian Zang. Application Analysis of Self-balancing Test Method [J]. Industrial Building,2006(S1):673-675.

5. Qiyuan Wang. Discussion on Self-balance Test Method in Static Load Test [J]. Shandong Industrial Technology,2017(03):280+231.

6. Xianlin Zhang. Comparison between Self-balancing Pile Test Method and Traditional Anchor Pile Test
Method [J].Geotechnical Engineering Technology, 2017,31(06):283-288.

7. ShanShan Lei. Study on bearing capacity mechanism of O-cell test pile [D]. Zhejiang Sci-Tech University,2019. (in Chinese)

8. Sixiong Wu. Application of self-balancing method to bearing capacity test of foundation pile in deep foundation pit $[\mathrm{J}]$.Fujian Construction Science and Technology,2016(01):11-13+10. 